\title{
Perspective on therapeutic and diagnostic potential of camel nanobodies for coronavirus disease-19 (COVID-19)
}

\author{
Salma Bessalah ${ }^{1}$ (i) $\cdot$ Samira Jebahi ${ }^{2} \cdot$ Naceur Mejri $^{2} \cdot$ Imed Salhi $^{1} \cdot$ Touhami Khorchani $^{1} \cdot$ Mohamed Hammadi $^{1}$
}

Received: 16 June 2020 / Accepted: 6 January 2021 / Published online: 22 January 2021

(c) King Abdulaziz City for Science and Technology 2021

\begin{abstract}
In this paper, we focus on the camelid nanobodies as a revolutionary therapy that can guide efforts to discover new drugs for Coronavirus disease (COVID-19). The small size property makes nanobodies capable of penetrating efficiently into tissues and recognizing cryptic antigens. Strong antigen affinity and stability in the gastrointestinal tract allow them to be used via oral administration. In fact, the use of nanobodies as inhalant can be directly delivered to the target organ, conferring high pulmonary drug concentrations and low systemic drug concentrations and minimal systemic side effects. For that, nanobodies are referred as a class of next-generation antibodies. Nanobodies permit the construction of multivalent formats that may achieve ultra-high neutralization potency and then may prevent mutational escape and can neutralize a wide range of SARS-CoV-2 variants. Due to their distinctive characteristics, nanobodies can be of great use in the development of promising treatment or preventive strategies against SARS-CoV-2 infection. In this review, the state-of-the-art of camel nanobodies design strategies against the virus including SARS-CoV-2 are critically summarized. The application of general nanotechnology was also discussed to mitigate and control emerging SARS-CoV-2 infection.
\end{abstract}

Keywords Antibodies engineering · Coronavirus disease (COVID-19) · Heavy chain antibodies · Pandemic · Singledomain antibody

\section{Introduction}

The coronavirus disease 2019 (COVID-19) is spreading rapidly since its first appearance in Wuhan, China, in December 2019. The occurrence of COVID-19 has been reported from more than 200 countries worldwide. On 16 December 2020, the number of confirmed cases has reached $73,476,721$

Salma Bessalah

bessalahsalma@yahoo.fr

https://scholar.google.com/scholar?hl=fr\&as_sdt $=0 \% 2 \mathrm{C}$

$5 \& \mathrm{q}=$ salma + bessalah $\& b t n G=$

Samira Jebahi

jbahisamira@yahoo.fr

https://scholar.google.com/scholar?hl=fr\&as_sdt=0\%2C

$5 \& \mathrm{q}=$ samira + jbahi $\& b$ tnG $=\& o q=$ samira + jbahi

Naceur Mejri

mejri.naceur@gmail.com

https://scholar.google.com/scholar?hl=fr\&as_sdt $=0 \% 2 \mathrm{C}$

$5 \& \mathrm{q}=$ naceur + mejri\&btnG $=$

Imed Salhi

imedsalhi@gmail.com

https://scholar.google.com/scholar?hl=fr\&as_sdt $=0 \% 2 \mathrm{C}$

$5 \& \mathrm{q}=\mathrm{imed}+$ salhi\&btnG $=$ including 1,635,464 deaths (https://coronavirus.jhu.edu/ map.html). Coronavirus was referred to as severe acute respiratory syndrome coronavirus 2 (SARS-CoV-2) and belongs to the beta-CoV genus of the Coronaviridae family (Lu et al. 2020). Phylogenetic analysis showed that SARS$\mathrm{CoV}-2$ genome has shared the highest nucleotide sequence identity to severe acute respiratory syndrome coronavirus

Touhami Khorchani touha2009@gmail.com

https://scholar.google.com/scholar?hl=fr\&as_sdt=0,5\& $\mathrm{q}=$ touhami+khorchani

Mohamed Hammadi mhammadi70@gmail.com

https://scholar.google.com/scholar?hl=fr\&as_sdt=0\%2C $5 \& \mathrm{q}=$ mohamed + hammadi $\& b \operatorname{tnG}=$

1 Livestock and Wildlife Laboratory, Arid Lands Institute (I.R.A), University of Gabès, 4119 Médenine, Tunisia

2 Laboratory on Energy and Matter for Nuclear Sciences Development (LR16CNSTN02), National Centre for Nuclear Sciences and Technologies, Sidi Thabet Technopark, 2020 Sidi Thabet, Tunisia, Pole technologique, BP 72, 2020 Sidi Thabet, Tunisia 
(SARS-CoV) and it is an enveloped, single-stranded, positive (+)-sense RNA virus with RNA genome of approximately 30 kilobases in length (Chen et al. 2020b). The emergence of SARS-CoV-2 has been marked as the third major outbreak caused by a new coronavirus in the past 2 decades, following SARS-CoV and Middle East respiratory syndrome coronavirus (MERS-CoV).

The genome of SARS-CoV-2 encodes four important structural proteins named spike (S), envelope (E), membrane (M), and nucleic capsid (N). Similar to other coronaviruses, the SARS-CoV-2 uses its $S$ protein to interact with cellular receptors (Wrapp et al. 2020b; Zhou et al. 2020b). In fact, $\mathrm{S}$ protein has been reported as a significant determinant in viral attachment, fusion and entry into target cells (Chen et al. 2020b). The $\mathrm{S}$ protein molecule contains two subunits, $\mathrm{S} 1$ and $\mathrm{S} 2$. The S1 subunit has a receptor-binding domain (RBD) that interacts with its host cell receptor, angiotensinconverting enzyme 2 (ACE2). On the other hand, the S2 subunit mediates fusion of the viral and cellular membranes for releasing viral RNA into the cytoplasm for its survival and replication. A structure model analysis shows that SARS-CoV-2 S protein binds to ACE2 with higher affinity than SARS-CoV S leading to rapid viral replication and then inducing an inflammatory response and provoking an accumulation of a large amounts of pro-inflammatory cytokines
(Wrapp et al. 2020b) (Fig. 1; adapted from de la Rica et al. 2020).

Compared to SARS-CoV, transmission route of SARSCoV-2 among humans seems to be greater (Petersen et al. 2020; Wang et al. 2020b). Several studies suggest that meteorological parameters may be important factors affecting the COVID-19 pandemic. In fact, the association between weather and SARS-CoV-2 spreading deserves special attention to analyze the conditions under which COVID-19 may resurge as a second wave of infections and to define the seasonal characterization of this pandemic. It has been reported that environmental factors, such as a higher temperature and a higher relative humidity, could decrease the virus spreading (Alkhowailed et al. 2020; Qi et al. 2020; Sajadi et al. 2020). Guo et al. (2020) used a distributed lag non-linear model to investigate the association between the COVID-19 incidence and meteorological factors in 415 sites from 190 countries. By comparison with seasonal coronaviruses OC43 and HKU1, Kissler et al. (2020) modelled possible scenarios for COVID-19 up to 2024. The results revealed that SARS$\mathrm{CoV}-2$ has the highest average of the basic reproductive rate $\left(R_{0}\right)$ in winter, which predicted winter cycles of COVID19 after the pandemic phase. In many parts of the world, numerous conditions were determined for a second wave of COVID-19. In fact, a recent study proved that a second wave
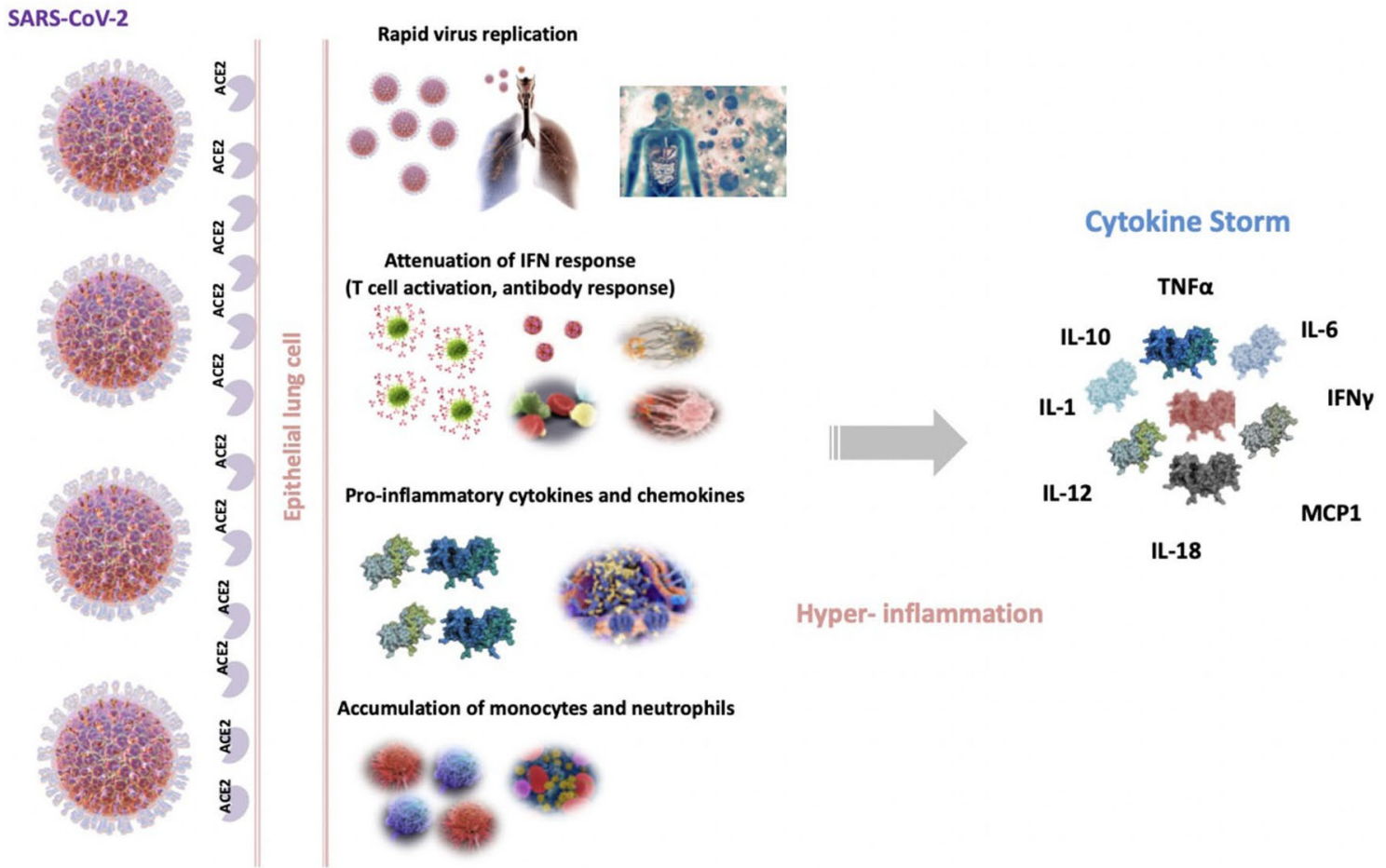

Hyper- inflammation

Fig. 1 Schematic representation of the origin of COVID-19 cytokine storm. Severe acute respiratory syndrome coronavirus 2 (SARS$\mathrm{CoV}-2$ ) enters cells via binding to angiotensin-converting enzyme 2 receptor (ACE2). The rapid viral replication in the first infection stage leads to an inflammatory response and provokes an accumulation of large amounts of pro-inflammatory cytokines referred as cytokine storm ( adapted from de la Rica et al. 2020) 
can occur across a broad range of plausible model input parameters governing epidemiological and social conditions, on the account of instabilities generated by behavior-disease interactions (Pedro et al. 2020). The same study found that the second wave tends to have a higher peak than the first although the efficacy of restrictions is greater than $40 \%$ and when the basic reproduction number $R_{0}$ is less than 2.4 . The letter estimated value has been proposed for SARS-CoV-2 similarly to that of SARS-CoV, the 1918 influenza pandemic and higher than that of MERS-CoV $\left(R_{0} 0.9\right)$ and the 2009 H1N1 influenza pandemic $\left(R_{0} 1.5\right)$ (Petersen et al. 2020). Similarly, more recent studies showed that the second wave seems to be significant especially when non-pharmaceutical measures are relaxed (Bontempi 2020; Cacciapaglia et al. 2020; Glass 2020; Renardy et al. 2020). In presence of novel pharmaceutical interventions, such as vaccines, a substantial third wave can be reversed. However, the present knowledge on chronology and durability of the immunity after natural infection with SARS-CoV-2 is incomplete (Prévost et al. 2020; Seow et al. 2020). The results of several studies showed that pre-existing immunity to common coronaviruses does not confer cross-protection against SARS-CoV-2 in vivo (Miyara et al. 2020). Taken together, the combination of several factors, such as the durability of protective immunity, the degree of cross-immunity between SARSCoV-2 and other coronavirus and the relaxation of effective mitigation measures, defines the dynamics of SARS-CoV-2. Population protective immunity has the potential to block the relentless spread of this pandemic. The percentage of the population that needs to be immunized to achieve this goal has been estimated to be $\sim 67 \%$ (Vashishtha and Kumar 2020). Based on these observations, we expect that the long-term dynamics of COVID-19 pandemic tends to come in waves over the next five years until the herd immunity builds-up naturally or through vaccination.

Clinically, symptoms of SARS-CoV-2 caused by COVID19 range from complete absence of symptoms (asymptomatic) to severe symptoms including fever, dry cough, shortness of breath, pneumonia and death (Mishra et al. 2020). As a matter of fact, diagnosis of COVID-19 can be achieved by several methods. These include CT radiography, a real-time reverse transcription-polymerase chain reaction (RT-PCR) and serological assays like point-of-care blood test (POCT) of IgM/IgG or enzyme-linked immunosorbent assay (ELISA kits) for SARS-CoV-2 (Li et al. 2020b). Intensified efforts have been made to develop preventive and therapeutic interventions strategies to combat SARSCoV-2. Importantly, both early diagnosis and therapeutic options are key requirements for managing the current pandemic. At the moment, more than 30 vaccine candidates have entered clinical trials to prevent COVID-19 infection in humans (Dong et al. 2020c). Indeed Sputnik vaccine based on recombinant adenoviral vectors $\mathrm{rAd} 26-\mathrm{S}$ and $\mathrm{rAd} 5-\mathrm{S}$ showed that the vaccine is safe, well tolerated, and induces strong humoral and cellular immune responses in $100 \%$ of healthy participants. Results showed that volunteers who received the heterologous $\mathrm{rAd} 26$ and $\mathrm{rAd} 5$ vaccine elicited the same titre of SARS-CoV-2 neutralizing antibodies as did people who had recovered from COVID-19 (Logunov et al. 2020). Currently, another procedure makes available a vaccine using mRNA constructed for the first time with a large scale by Pfizer Company. This vaccine solicits the activation of both the humoral and the cellular immune responses. Pfizer's vaccine is found to be $90 \%$ effective in preventing COVID-19. It appears that in human organism, many cell types are able to internalize these mRNAs which are then translated into proteins. This process mimics what happens in a natural infection, the cell infected by the antigens (from the mRNA) presents them via its Major Histocompatibility Complex (MHC) to the immune cells. This vaccine appears to stimulate both cellular and humoral immune responses (Jackson et al. 2020). However, vaccination is only useful in a preventive environment and cannot be applied for immunodeficient patients or pregnant women.

Among the different strategies for treatment and prevention of COVID-19, passive immunotherapy using singledomain antibodies (sdAbs), namely nanobodies (Nbs), may be of great benefit. Nbs derived from heavy-chain-only antibodies (HcAbs) are only found in camelids and some cartilaginous fish (Hamers-Casterman et al. 1993; Stanfield et al. 2004). Camelid-derived sdAbs, known as VHHs, exhibit unique characteristics in comparison with conventional antibodies and their recombinant fragments. The specific properties of VHHs, like high affinity, small size (only $15 \mathrm{kDa}$ ) and easy manipulation, make them promise tools for a wide range of applications including virus neutralization. In the present review, we summarize recent findings on $\mathrm{Nbs}$ and how they can be used as a diagnostic and therapeutic reagent that control and mitigate the emergence of COVID-19.

\section{Current treatment strategies of SARS-CoV-2}

\section{Antiviral medications}

As reported previously, numerous antiviral drugs may have great potential against SARS-CoV-2 and some of them are in phase III trials for COVID-19.

Among these antiviral drugs, Remdesivir, an adenosine analogue, that can block viral RNA replication, might have some clinical efficacy against SARS-CoV-2, similar to prior studies using them against SARS (Sheahan et al. 2017; Agostini et al. 2018). Chloroquine, a 9-aminoquinoline, used in therapy of malaria can be effective in the treatment of patients with COVID-19. Therefore, recent studies reported its strong activity against SARS-CoV-2 through different 
mechanims of action (Gao et al. 2020; Gautret et al. 2020). Other therapeutic agents, including Lopinavir/Ritonavir, Favipiravir (T-705) and Arbidol could also be the choices for the management of COVID-19/SARS-CoV-2 infection (Tse et al. 2020; Wang et al. 2020c; Lu 2020).

\section{Plasma therapy and neutralizing antibodies}

Passive immunisation by administration of antibodies (immunoglobulins: $\operatorname{IgG}$ ) has been known for more than one hundred years as a very efficient tool and affordable solution for immediate treatment against infectious diseases. Thus, the role of plasma therapy in protection from SARS-CoV-2 infection has been thoroughly reviewed elsewhere (Klasse and Moore 2020; Wang et al. 2020c). Because of the high morbidity and mortality associated with COVID-19, the plasma of some convalescent SARS-CoV-2-infected patients represents an easily applied for treatment of COVID-19 infection clinically.

Patients with resolved COVID-19 infection will develop a specific immune defense against the SARS-CoV-2. Plasma from convalescent donors provides an immediate immunity to passively immunized persons that can last from weeks to months. Blood plasma from recovered patients could boost the immune state, limit the virus reproduction and then reduce the damage in patients with SARS-CoV-2 infection. However, functional antibody titers may be the determining factor (e.g., 50\% plaque-reduction neutralization titer: PRNT50) to obtain effective therapeutic results as reported previously with MERS-CoV infection (Ko et al. 2018). Also, a donor selection criteria need to be strictly enforced to ensure the safety of plasma IgG specific to SARS-CoV-2. Therapeutic trials based on the administration of plasma with high antibody titers may be more beneficial than lowtiter plasma in non-incubated patients, particularly when administered within $72 \mathrm{~h}$ of COVID-19 diagnosis. However, the use of convalescent plasma did not always lead to the recovery (Gharbharan et al. 2020).

Several human monoclonal antibodies (mAbs) have been isolated and characterized (Ju et al. 2020; Wang et al. 2020a; Chen et al. 2020a). Developed mAbs showed promising neutralization activity against SARS-CoV-2. In a recent review paper, Renn et al. (2020) summarized current development of neutralizing antibodies. Some of them have entered clinical trials or are in preclinical stages. Despite the large number of neutralizing antibodies identified until now, there are still many challenges. In fact, potential problems related to somatic mutations and antibody-dependent enhancement (ADE) may reduce the efficacy of a single neutralizing antibodies. To fight these problems, antibody cocktails can be used. Some of them have entered clinical evaluation. On the other hand, multiple research studies are focused on antibody fragments that can be used in combination to balance neutralization and ADE side effects (Zhou et al. 2020a; Huo et al. 2020).

\section{Nbs as new approach for the prevention and treatment of COVID-19}

\section{Camel heavy chain antibodies and Nbs}

In addition to conventional antibodies (heterotetrameric structure with two heavy and two light chains) produced by all mammals, camelidae members family including Old World species (camels and dromedaries) and New World species (llamas, alpacas, and vicuñas) are able to produce non-conventional antibodies (Hamers-Casterman et al. 1993). Structures of these IgG are devoid of the complete light chain and the first constant heavy domain $\mathrm{CH} 1$ and
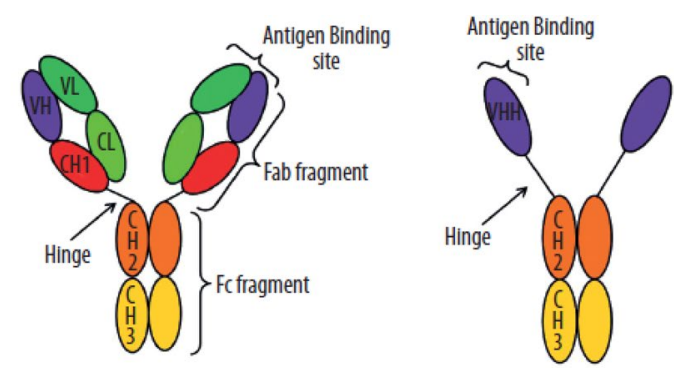

a Conventional antibodies

b Homodimeric antibodies

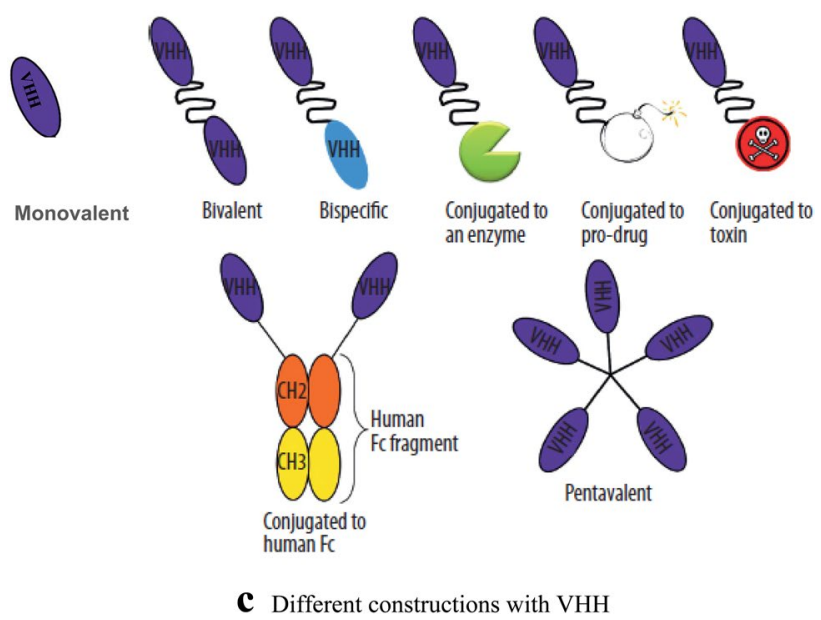

Fig. 2 Schematic diagram of camelid antibodies (a, b) and different Single-domain antibody fragment (VHH) constructions (c). a The common structure of conventional antibodies: The antigen-binding fragment (Fab) consisting of Variable Light (VL), Variable Heavy (VH), Constant Light (CL) and Constant Heavy 1 (CH1) domains. b The structure of homodimeric camelid antibody: The antigen-binding fragment lack the VL, CL and CH1 domains and named Singledomain antibody fragment (VHH). c Different VHH constructions (adapted from Smolarek et al. 2012) 
then named HcAbs. The account of HcAbs in the sera varies between camel species. It can reach 50-80\% in Camelus bactrianus and Camelus dromedarius; however, it does not exceed $25 \%$ in the serum of the South American camelids (alpacas and llamas) (De Simone et al. 2008; Blanc et al. 2009).

$\mathrm{HcAbs}$ were reffered to as $\operatorname{IgG} 2$ (IgG2a and $\operatorname{IgG} 2 \mathrm{~b}$ ) and IgG3 IgG-subclasses to distinguish them from conventional antibodies (IgG1). Despite their particular structure, HcAbs antibodies are fully functional and still able to bind antigens with a high affinity through their antigen-binding site known as VHH (Fig. 2; adapted from Smolarek et al. 2012).

\section{Structure and peculiar characteristics of VHHs}

Despite it shares general structural features with human variable heavy domain ( $\mathrm{VH})$, the camelid heavy chain variable named as $\mathrm{VHH}$, with a molecular weight of $15 \mathrm{kDa}$, presents an important difference with VH. In fact, there are four major amino acid substitutions observed in the framework region 2 (FR2) that substitute the hydrophobic residues (involved in the VH/VL interaction in conventional antibodies) by more hydrophilic amino acids (Nguyen et al. 2001). These substitutions compensate the lack of the variable light domain (VL) and confer the higher solubility of VHHs when compared to other single-domain antibodies. Additionally, complementarity determining regions (CDRs) exhibit a long CDR3 loop that increases the antigen- binding loop size in VHHs and enables theme to bind concave epitopes that cannot be recognized by traditional antibodies ((Muyldermans et al. 1994; Vu et al. 1997). The stability of extended CDR3 loops is maintained by a disulfide bond between CDR1 and CDR3 or between FR2 and CDR3. These particular features increase the stability and the solubility of $\mathrm{VHH}$ even under denaturing conditions or high temperatures (Van der Linden et al. 1999; Dumoulin et al. 2002; Conrath et al. 2005; Kunz et al. 2018). Moreover, VHHs are easily engineered with high yields and low-cost production using various expression systems (Liu and Huang 2018; De Marco 2020).

The most important characteristics of $\mathrm{VHH}$ fragments include negligible immunogenicity in the human body, rapid penetration into the tissue, a nanomolar affinity for their target and flexible formatting (multimerization). More importantly, the high stability of VHHs under harsh conditions (in the presence of proteases, chaotropic agents as well as at extreme pHs) facilitate their administration by inhaled delivery for the treatment of respiratory diseases. These distinctive properties provide VHHs numerous advantages compared to conventional antibodies and their recombinant fragments and make them a powerful tool for immunotherapy as well as immunodiagnostics immunoassay development.

\section{Production process of VHHs}

Over three decades ago, the phage display technology has been shown to be an effective and efficient platform to develop and produce therapeutic antibodies. Numerous recombinant antibodies with desired functional properties are selected from immune, naïve, or synthetic libraries via phage display technology. This fast methodology enables the selection of Nbs with a reasonable specificity and affinity by successive rounds of bio-panning (Silacci et al. 2005).

Nbs are successfully expressed in a variety of expression systems including prokaryotic, eukaryotic and plant hosts. Nbs are characterized by large-scale production, solubility and stability compared to conventional antibody fragments (antigen-binding fragments (Fab) or single-chain variable fragments $(\mathrm{scFv}))$ that can aggregate due to their low solubility (Van der Linden et al. 1999).

Other strategies, such as ribosome display and yeast surface display can be used for the selection of specific VHHs. The mono-domain format of VHH offers significant advantages in cost of production and engineering compared to conventional antibodies.

\section{Camel nanobodies: promising therapeutic tools to combat the emerging pandemic virus}

\section{Neutralizing VHH against viral zoonosis}

Due to their peculiar properties, rapid progress has been made regarding the production of $\mathrm{VHH}$ domains for therapeutic and diagnostic applications (Wesolowski et al. 2009; Khodabakhsh et al. 2018; Lafaye and Li 2018; Sanaei et al. 2019; Chames and Rothbauer 2020). It has been demonstrated that these Nbs can be easily engineered without loss of functionality. Currently, several Nbs produced by Ablynx (now Sanofi), are in different clinical trials and with Caplacizumab, the European Medicines Agency (EMA) and the US Food and Drug Administration (FDA) approved the first sdAb-based medicine for adults in November 2018 and in February 2019, respectively (Morrison 2019; Jovčevska and Muyldermans 2020). Viral neutralizing sdAb has been described as valuable biomolecules, with high potentials, able to perturb different steps in the viral life cycle with many examples of viral neutralizing Nbs (De Vlieger et al. 2019; Sroga et al. 2020). These Nbs have been generated from an immune or synthetic phage display library against a wide range of target classes. Table 1 shows Nbs selected for the prevention and treatment of infectious viral diseases including that of SARS-CoV-2.

For example, sdAb specific for influenza viruses has been successfully isolated through selections against the nucleoprotein and M2 ion channel protein of Influenza A, the neuraminidase and trimeric spike protein and hemagglutinin of 
Table 1 Nanobodies-based therapeutic tools for viral infection diseases including emerging corona viruses

\begin{tabular}{|c|c|c|c|c|}
\hline Virus & Target & Nanobodies & Source & References \\
\hline MERS-CoV & RBD & $\begin{array}{l}\text { Monomeric VHH: } \\
\text { NbMS10 }\end{array}$ & $\begin{array}{l}\text { Llama immune VHH } \\
\text { library (phage display) }\end{array}$ & Zhao et al. (2018) \\
\hline MERS-CoV & RBD & $\begin{array}{l}\text { VHH and camel/ } \\
\text { human chimeric } \\
\text { (HcAbs:HCAb-83) }\end{array}$ & $\begin{array}{l}\text { Dromedary camel immune } \\
\text { VHH library (phage } \\
\text { display) }\end{array}$ & Raj et al. (2018) \\
\hline MERS-CoV & RBD & $\begin{array}{l}\text { Mono-Nb, dimeric } \mathrm{Nb} \\
(\mathrm{Di}-\mathrm{Nb}) \text { and Trimeric } \mathrm{Nb} \\
(\mathrm{Tri}-\mathrm{Nb})\end{array}$ & $\begin{array}{l}\text { Llama immune VHH } \\
\text { library (phage display) }\end{array}$ & He et al. (2019) \\
\hline SARS-CoV-2 & RBD & $\begin{array}{l}\text { Monomeric VHH: NIH- } \\
\text { CoVnb-112 }\end{array}$ & $\begin{array}{l}\text { Llama immune VHH } \\
\text { library (phage display) }\end{array}$ & Esparza and Brody (2020) \\
\hline SARS-CoV-2 & RBD & $\begin{array}{l}\text { Multivalent } \mathrm{Nb}: \mathrm{Nb}_{2} 1_{3} \text { and } \\
\mathrm{Nb}_{2} \mathrm{O}_{3}\end{array}$ & $\begin{array}{l}\text { Llama immune VHH } \\
\text { library (phage display) }\end{array}$ & Xiang et al. (2020) \\
\hline SARS-CoV-2 & RBD & Monomeric VHH & $\begin{array}{l}\text { Alpaca immune VHH } \\
\text { library (phage display) }\end{array}$ & Nieto et al. (2020) \\
\hline SARS-CoV-2 & RBD & $\begin{array}{l}\text { Monomeric VHH: } \\
\text { NM1226, NM1228 and } \\
\text { NM1230 }\end{array}$ & $\begin{array}{l}\text { Alpaca immune VHH } \\
\text { library (phage display) }\end{array}$ & Wagner et al. (2020) \\
\hline SARS-CoV-2 & $\mathrm{RBD}$ & Trimeric Nb: mNb6-tri & $\begin{array}{l}\text { Llama synthetic VHH } \\
\text { library (yeast display) }\end{array}$ & Schoof et al. (2020) \\
\hline SARS-CoV-2 & $\mathrm{RBD}$ & $\begin{array}{l}\text { Monomeric VHH: H11-D4 } \\
\text { and H11-H4; chimeric } \\
\text { fusions:H11-H4-Fc and } \\
\text { H11-D4-Fc }\end{array}$ & Naïve llama VHH library & Huo et al. (2020) \\
\hline SARS-CoV-2 & RBD & Monomeric VHH: Ty1 & $\begin{array}{l}\text { Alpaca immune VHH } \\
\text { library (phage display) }\end{array}$ & Hanke et al. (2020) \\
\hline SARS-CoV-2 & RBD & Monovalent Nb: Nb11-59 & $\begin{array}{l}\text { Camel immune VHH } \\
\text { library (phage display) }\end{array}$ & Gai et al. (2020) \\
\hline SARS-CoV-2 & RBD & Monomeric VHH: SR31 & $\begin{array}{l}\text { Synthetic sdAb phage } \\
\text { display library }\end{array}$ & Yao et al. (2020) \\
\hline SARS-CoV-2 & RBD & $\begin{array}{l}\text { Monovalent VHH: } 2 \mathrm{~F} 2 \text {, } \\
3 \mathrm{~F} 11 \text { and } 5 \mathrm{~F} 8 \\
\text { Fc-fused sdAbs }\end{array}$ & $\begin{array}{l}\text { Synthetic sdAb phage } \\
\text { display library }\end{array}$ & Chi et al. (2020) \\
\hline SARS-CoV-2 & RBD & Sybody Sb23 & $\begin{array}{l}\text { Three sybody librar- } \\
\text { ies (concave, loop and } \\
\text { convex) }\end{array}$ & Custódio et al. (2020) \\
\hline SARS-CoV-2 & $\mathrm{RBD}$ & Sybody MR3 & $\begin{array}{l}\text { Three sybody librar- } \\
\text { ies (concave, loop and } \\
\text { convex) }\end{array}$ & Li et al. (2020a) \\
\hline SARS-CoV-2 & RBD & Sybodies & $\begin{array}{l}\text { Three large combinatorial } \\
\text { libraries, using ribosome } \\
\text { and phage display }\end{array}$ & Walter et al. (2020) \\
\hline SARS-CoV-2 & $\begin{array}{l}\text { Recombinant SARS-CoV-2 } \\
\text { S protein }\end{array}$ & $\begin{array}{l}\text { Bispecific VHH-Fc anti- } \\
\text { body, Tri-specifc VHH- } \\
\text { Fc antibody }\end{array}$ & $\begin{array}{l}\text { Naïve and synthetic llama } \\
\text { VHH library }\end{array}$ & Dong et al. $(2020 a, b, c)$ \\
\hline SARS-CoV-2 & $\mathrm{RBD}, \mathrm{S} 1$ protein & $\begin{array}{l}\text { Human single-domain } \\
\text { antibodies n } 3130\end{array}$ & Naïve antibody libraries & Wu et al. (2020) \\
\hline $\begin{array}{l}\text { SARS-CoV-2, MERS- } \\
\text { CoV, SARS-CoV-1 }\end{array}$ & $\begin{array}{l}\text { prefusion-stabilized coro- } \\
\text { navirus spikes }\end{array}$ & $\begin{array}{l}\text { Bivalent VHH:VHH-72 } \\
\text { VHH-55, VHH-72-Fc }\end{array}$ & $\begin{array}{l}\text { Llama immune VHH } \\
\text { library (phage display) }\end{array}$ & Wrapp et al. (2020a) \\
\hline Influenza $A$ and $B$ viruses & Hemaglutinins & $\begin{array}{l}\text { Multivalent VHH: } \\
\text { MD3606 }\end{array}$ & $\begin{array}{l}\text { Llama immune VHH } \\
\text { library }\end{array}$ & Laursen et al. (2018) \\
\hline H1N1 & Hemaglutinin & bivalent VHH: R1a-B6 & $\begin{array}{l}\text { Alpaca immune VHH } \\
\text { library (phage display) }\end{array}$ & Hufton et al. (2014) \\
\hline Respiratory syncytial virus & Fusion $(\mathrm{F})$ protein & $\begin{array}{l}\text { Trivalent nanobody: ALX- } \\
0171\end{array}$ & $\begin{array}{l}\text { Llama immune VHH } \\
\text { library (phage display) }\end{array}$ & $\begin{array}{l}\text { Van Heeke et al. } \\
\text { (2016), Detalle et al. } \\
\text { (2015), Wilken et al. } \\
(2017)\end{array}$ \\
\hline
\end{tabular}


Table 1 (continued)

\begin{tabular}{|c|c|c|c|c|}
\hline Virus & Target & Nanobodies & Source & References \\
\hline Hepatitis B virus & Capsid protein: $\mathrm{HBcAg}$ & VHH intrabodies & $\begin{array}{l}\text { Llama immune VHH } \\
\text { library (phage display) }\end{array}$ & Serruys et al. (2010) \\
\hline HIV & gp120 & $\begin{array}{l}\text { Monovalent VHH: A12, } \\
\text { C8, and D17, }\end{array}$ & $\begin{array}{l}\text { Llama immune VHH } \\
\text { library (phage display) }\end{array}$ & Forsman et al. (2008) \\
\hline HIV & gp140 & Monovalent VHH: 2E7 & $\begin{array}{l}\text { Llama immune VHH } \\
\text { library (phage display) }\end{array}$ & Strokappe et al. (2012) \\
\hline Influenza A virus & Nucleoprotein (NP) & $\begin{array}{l}\text { Monovalent VHH:NP- } \\
\text { VHHs }\end{array}$ & $\begin{array}{l}\text { Alpaca immune VHH } \\
\text { library (phage display) }\end{array}$ & Ashour et al. (2015) \\
\hline Influenza A virus & $\begin{array}{l}\text { Native M2 ion channel } \\
\text { protein }\end{array}$ & Monovalent VHH: M2-7A & $\begin{array}{l}\text { Synthetic Camel single- } \\
\text { domain antibody (VHH) } \\
\text { libraries }\end{array}$ & Wei et al. (2011) \\
\hline H5N1 & Hemaglutinin & Trivalent VHH & $\begin{array}{l}\text { Llama immune VHH } \\
\text { library (phage display) }\end{array}$ & Hultberg et al. (2011) \\
\hline $\mathrm{H} 5 \mathrm{~N} 1$ & $\begin{array}{l}\text { Influenza virus neurami- } \\
\text { nidase (NA) Neurami- } \\
\text { nidase }\end{array}$ & $\begin{array}{l}\text { Bivalent VHH: N1-VHHb, } \\
\text { N1-VHH-Fc }\end{array}$ & $\begin{array}{l}\text { Alpaca immune VHH } \\
\text { library (phage display) }\end{array}$ & Cardoso et al. (2014) \\
\hline Poliovirus type 1 & Capsid & $\begin{array}{l}\text { Monovalent VHH: } \\
\text { PVSS21E }\end{array}$ & $\begin{array}{c}\text { Dromedary immune VHH } \\
\text { library (phage display) }\end{array}$ & Strauss et al. (2016) \\
\hline Norovirus & VLPs & $\begin{array}{l}\text { Monomerci: Nano-26 and } \\
\text { Nano- } 85\end{array}$ & $\begin{array}{l}\text { Alpaca immune VHH } \\
\text { library (phage display) }\end{array}$ & Koromyslova et al. (2017) \\
\hline Rotavirus & VP6 inner capsid protein & Monovalent VHH & $\begin{array}{l}\text { Llama immune VHH } \\
\text { library (phage display) }\end{array}$ & Van der Vaart et al. (2006) \\
\hline $\begin{array}{l}\text { Chikungunya virus } \\
\text { (CHIKV) }\end{array}$ & $\begin{array}{l}\text { CHIKV virus-like particles } \\
\text { contained the capsid, E1 } \\
\text { and E2 proteins }\end{array}$ & $\mathrm{CC} 3 \mathrm{VHH}$ & $\begin{array}{l}\text { Llama immune VHH } \\
\text { library (phage display) }\end{array}$ & Liu et al. (2019) \\
\hline Ebola virus & $\begin{array}{l}\text { Recombinant EBOV GP } \\
\text { and EBOV VLPs }\end{array}$ & sdAbs & $\begin{array}{l}\text { Llama immune VHH } \\
\text { library (phage display) }\end{array}$ & Liu et al. (2017) \\
\hline
\end{tabular}

H5N1 and H1N1 (Wei et al. 2011; Hultberg et al. 2011; Cardoso et al. 2014; Hufton et al. 2014; Ashour et al. 2015; Laursen et al. 2018). An sdAb-specific viral protein (PV1) of poliovirus (PV) was identified from the immunised phage display library. The mechanism by which these VHHs reduce viral loads is by blocking the ligand-receptor interactions (Strauss et al. 2016). Human norovirus is classified among the leading cause of gastroenteritis worldwide. Several Nbs against virus-like particles (VLPs) of norovirus have shown promise for disease treatment (Koromyslova and Hansman 2017).

Ebola virus (EBOV) is extremely virulent and causes fatal hemorrhagic fever in $\sim 50 \%$ of the cases. The interaction between viral envelope glycoprotein GP and host cell receptors plays a critical role in pathogenicity of this virus. An immune $\mathrm{sdAb}$ phage display library derived from a llama immunized with killed EBOV and recombinant GP was constructed and SdAbs specific for Ebola GP were selected and evaluated for their affinity and thermal stability (Liu et al. 2017). Also, monovalent, bivalent and trivalent VHHs targeting the glycoproteins, gp120 and gp41 of VIH have been generated to disrupt virus entry into cluster of differentiation 4 (CD4) $^{+} \mathrm{T}$ cells (Forsman et al. 2008; Strokappe et al. 2012; Weiss and Verrips 2019). Chikungunya virus
(CHIKV) is a member of Togaviridae family that causes severe joint pain which is associated with fever, rash and headache. Five anti-CHIKV sdAbs have been generated in immunized llamas. These viral neutralizing sdAbs have been successfully isolated through selections against the CHIKV VLPs (Liu et al. 2019).

Nbs developed against the core antigen of hepatitis $B$ (HBcAg) have an effect on the viral life cycle in HBV-transfected hepatocytes (Serruys et al. 2010). Moreover, VHHs directed against rotavirus serotype $\mathrm{G} 3$ reduce morbidity of rotavirus-induced diarrhea in vivo (Van der Vaart et al. 2006). In another example, it has been shown by Terryn et al. (2016) that multi-merization of VHH domains significantly improves protection of mice from lethal rabies infection.

Nbs have been described as inhaled bio-therapeutics for lung diseases. Human respiratory syncytial virus (RSV) belongs to the Pneumoviridae family and represents the most important cause of lower respiratory tract infections in young infants. Successful phase I/IIa clinical trials were completed for an anti-RSV VHH domain called ALX-0171 (Detalle et al. 2015; Van Heeke et al. 2017; Wilken and McPherson 2018). Neutralizing activities of ALX-0171 were compared to Palivizumab, a marketed neutralizing

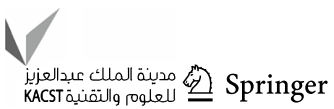


monoclonal antibody, and it was demonstrated that ALX0171 inhibits virus replication in $87 \%$ of viruses tested versus $18 \%$ observed with Palivizumab administration. In addition, to develop lung-targeting drugs, Nbs targeting pulmonary surfactant protein A (SPA) have been isolated. The authors showed fast accumulation of selected $\mathrm{Nbs}$ in the lungs (Wang et al. 2015).

Nbs against different coronavirus species have been isolated and characterized to block interaction between virus and host cell. As example, Abs targeting RBD of MERS$\mathrm{CoV}$ were identified and selected from the immunized dromedary and it was shown that camel/human chimeric HcAbs bind to their target with picomolar affinity (Raj et al. 2018). In addition, Zhao and colleagues panned an immune VHH library derived from llama immunized with a recombinant MERS-CoV RBD protein, and isolated monomeric VHH (Mono-Nb, NbMS10) (Zhao et al. 2018). He et al. (2019) generated two oligomeric Nbs, dimeric and trimeric Nbs, from an immunized library directed against the RBD of MERS-CoV. According to a multiple recent studies, VHHs exhibited high neutralization potency SARS-CoV-2. Humanized sdAbs-binding SARS-CoV-2 RBD proteins have been discovered in a synthetic sdAb phage display library (Chi et al. 2020). The inhibition efficiency on SARS-CoV-2 pp and affinity kinetics was tested in vitro. These Nbs, named $2 \mathrm{~F} 2,3 \mathrm{~F} 11$ and $5 \mathrm{~F} 8$ could be very advantageous to find new specific drugs to prevent SARS-CoV-2 infection by inhibiting membrane fusion between RBDs of the viral Spike and their host cell receptors and then blocks the entry of

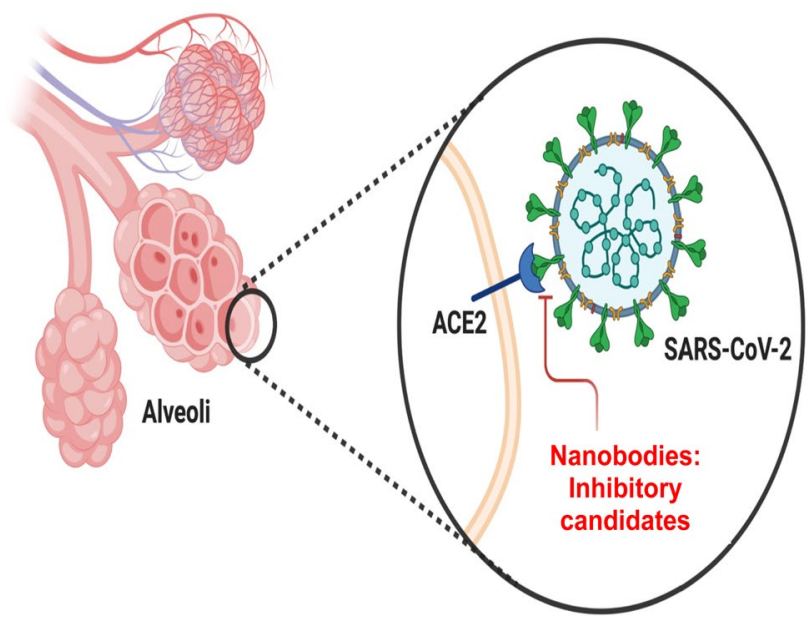

Fig. 3 The potential mechanisms of SARS-CoV-2 neutralization by nanobodies. The major therapeutic goal is to develop inhibitory agents that disrupt the interaction between the receptor-binding domain of SARS-CoV-2 (green color) with its host cell receptor (angiotensin-converting enzyme 2: ACE2). Nanobodies bound directly to the receptor-binding domain (RBD) and competed with the ACE2 receptor from the surface of human cells (adapted from Esparza et al. 2020)
SARS-CoV-2 into cells (Fig. 3; adapted from Esparza et al. 2020). Another illustration of a VHH against SARS-CoV-2 is VHHs against prefusion-stabilized MERS-CoV and SARS-CoV-1 spikes of Betacoronaviruses. These neutralizing sdAbs were isolated from immunized llamas and it was demonstrated that engineered bivalent Nbs exhibits cross-reactivity against SARS-CoV-1 RBD and SARSCoV-2 RBD and able to neutralize SARS-CoV-2 S pseudoviruses with high affinity (Wrapp et al. 2020a). Using a combiation of two llama VHH libraries, humanized VHH has been constructed (Dong et al. 2020a, b). In their studies, Dong and collaborators demonstrated that multi-specific antibodies showed better affinity and avidity than individual monoclonal VHH-Fcs. More importantly, these multi-specific antibodies showed more potent neutralization activity than a combination of monoclonal antibodies. Hanke et al. (2020) reported the isolation of a monomeric $\mathrm{Nb}$ (Ty1) from immunised alpaca. The highly specificity and high-affinity binding of Ty1 to the RBD have been confirmed. Hanke and colleagues, suggest that the generation of homodimeric or trimeric formats is likely to further increase its neutralization activity. More recently, Schoof et al. (2020) have successfully isolated a panel of Nbs, from synthetic Nbs library, that bind to multiple epitopes on Spike. These Nbs were divided into two classes. Class I bound directly to the RBD and competed with the ACE2 receptor from the surface of human cells. While class II recognized another binding region leading to modification of structural conformation of the RBD so that it cannot recognize ACE2 receptor. Structural analyses have clearly shown that the binding domain of class II Nbs occurred on a protected area on the spike protein well away from the RBD. Two class I Nbs designated Nb6 and $\mathrm{Nb} 11$ bound to both open and closed conformations of Spike. To enhance the reactivity, Nb6 has been considered to make dimers and trimers. The novel structures inhibited more strongly the trimeric spike $\mathrm{S}$ protein by binding to more than one RBD on its surface. To assess the binding efficacy the measurement of IC50 revealed that Nb6 had an IC50 of 2 micromolar, while the Nb6-trimeric form (mNb6tri) was $1.2 \mathrm{nM}$. In this assay, the trimeric form showed two-thousand-fold improvement in efficacy. This result was confirmed in a test of Vero cell infection with real SARS$\mathrm{CoV}-2$ coronavirus where $\mathrm{mNb6}$-tri was able to prevent viral attack with an IC50 of 160 picomolar, which is truly impressive. Moreover, a mutation generate on mNb6-tri reached femtomolar affinity for SARS-CoV-2. Even if at the prophylactic level, Sputnik vaccine and mRNA vaccine have been shown to be effective. The therapeutic mNb6-tri is very interesting with its high interaction with RBD as well as its stability after aerosolization, lyophilization and heat treatment (Schroof el al. 2020). It is easy and not expensive to obtain this $\mathrm{Nb}$ in large number by cultivation on yeast. The study of its efficacy on patient's infected with SARS-CoV-2 
needs to be monitored. In a similar study, the identification and characterization of two other high-affinity Nbs (H11-D4 and $\mathrm{H} 11-\mathrm{H} 4$ ) have been reported (Huo et al. 2020). Both H11-D4 and H11-H4 Nbs blocked RBD binding to ACE2. Furthermore, in the same study, a bivalent Human Fc-Nb fusion (homodimeric chimeric protein) showed neutralizing activity against SARS-CoV-2 and additive neutralization with the SARS-CoV-1/2 antibody CR3022. In fact, it has been demonstrated that the CR3022 and these Nbs recognized non-overlapping epitopes on RBD. Interestingly, such additive combinations are a well-known strategy to reduce mutational escape.

In a recent study, three potent $\mathrm{Nbs}(\mathrm{Nb} 21, \mathrm{Nb} 20$ and $\mathrm{Nb89}$ ) with picomolar affinity have been isolated from a Llama immune VHH library (Xiang et al. 2020). Multivalent Nbs have been constructed to enhance the antiviral activities. Results showed that up to $\sim 30$-fold improvement of inhibitory activity was observed with an IC50 of 1.3 picomolar and 4.1 picomolar for the homotrimeric constructs of $\mathrm{Nb}_{2} 1_{3}$ and $\mathrm{Nb}_{2} \mathrm{O}_{3}$, respectively. Importantly, multivalent constructs keep excellent physicochemical properties after lyophilization and aerosolization make them suitable for inhalation administration. Nieto et al. (2020) reported a rapid selection of monomeric $\mathrm{Nb}$ with sub-nanomolar affinity. Nevertheless, the neutralization activity of this $\mathrm{Nb}$ against SARSCoV-2 pseudo-virus needs to be achieved. In another study, Nbs targeting different spike antigens (RBD, S1 domain or homo-trimeric spike) with high neutralizing potency have been successfully isolated from immunised alpaca $\mathrm{VHH}$ library (Wagner et al. 2020). Using these Nbs (NM1226, NM1228 and NM1230), a competitive multiplex binding assay called "NeutrobodyPlex" has been developed. Authors demonstrated that NeutrobodyPlex approach using RBDspecific Nbs was more efficacious than conventional antibodies which showed cross-reactive signals. Furthermore, the test has been validated by analyzing serum samples collected from 18 patients and 4 healthy donors in comparison to standard assays. It can determine whether the examined people carry neutralizing antibodies preventing re-infection. Interestingly, this novel diagnostic test opens the door to surveil the emergence of neutralizing antibodies in infected patients. Thus, it might be useful during vaccination campaigns in the future.

Nbs library derived from immunised camel has been constructed (Gai et al. 2020). It has been shown that seven Nbs represented good binding capacity to RBD including eight SARS-CoV2-RBD mutants. Among these candidates, Nb11-59 exhibited the best neutralizing activities with a good stability. According to these results, Nb11-59 might be novel therapeutic molecule, as an inhaled drug, for COVID19 treatment. In a study, 63 sybodies, against the SARSCoV-2 RBD, were generated from three large combinatorial libraries, using ribosome and phage display. Described flycode technology provides new opportunities for passive immunization to protect people against SARS-CoV-2 escape mutants (Walter et al. 2020). In addition, other studies reported the rapid isolation and characterization of potent synthetic Nbs which neutralize SARS-CoV-2 pseudo-viruses with high affinity (sybodies MR3 and Sb23) (Custodio et al. 2020; Li et al. 2020a). The last one (Sb23) can also bind the RBD in both "up" and "down" conformation (Custodio et al. 2020). Also, Yao et al. (2020) identified a new synthetic Nb. Selected sybody (named SR31) displayed poor neutralization activity against SARS-CoV-2 pseudo-virus. However, when fusioned with two other sybodies, increased binding affinities and neutralizing activities were observed. According to this result, SR31 cannot be used alone. Nevertheless, it may be combined with monoclonal antibodies or other antibody fragments to improve affinity and potency.

In another study, several $\mathrm{Nbs}$ that bind to the SARSCoV-2 RBD have been isolated (Esparza and Brody 2020). Among those, the lead therapeutic candidate named NIHCoVnb-112 showed high affinity in monomeric form and blocked interaction between ACE2 and several variant forms of the spike protein. Furthermore, Wu et al. (2020) selected fully human single-domain antibodies against five types of epitopes on SARS-CoV-2 RBD, using phage-displayed VHH library by grafting naïve CDRs into FR regions. The use of these Nbs may represent a novel approach to battle against COVID-19 given that human showed immunogenicity towards other antibody fragments (Wu et al. 2020).

\section{Nanobodies as modulators of inflammation}

Immune responses play a key role during SARS-CoV-2 virus infection. The latest reports suggest that acute respiratory distress syndrome (ARDS) is the common immunopathological event for this infectious disease (Shi et al. 2020; Wen et al. 2020). One of the main mechanisms for ARDS is the uncontrolled systemic inflammation, named as cytokine storm, resulting from the release of large amounts of pro-inflammatory cytokines (interferons: IFN- $\alpha$ and IFN$\gamma$; interleukins: IL-1 $\beta$, IL-2, IL-4, IL-6, IL-8, IL-9, IL-10, IL-12, IL-18 and IL-33; tumour necrosis factor: TNF- $\alpha$; transforming growth factor $\beta$ : TGF $\beta$; etc.) and chemokines (CCL2, CCL3, CCL5, CXCL8, CXCL9, CXCL10, etc.) by immune effector cells upon viral infection (Fig. 1) (Ong et al. 2020; Li et al. 2020a, b; de la Rica et al. 2020). Given the pivotal role of these proteins during inflammation, specific inhibitors of their activities might be useful as new tools to modulate immune functions in COVID-19 patients (Shi et al. 2020).

The generation of Nbs directed against chemokines, cytokines, and ecto-enzymes can be tailored to modulate inflammation responses and then beneficial for the recovery 
of COVID-19 patients. Nbs that modulate immune function have been successfully generated in immunized camelids. Several reports have been published in raising sdAbs directed against cytokine by phage display technology (Nosenko et al. 2017). For example, TNF $\alpha$ is an important cytokine implicated in a number of chronic inflammatory disorders. TNF $\alpha$-blocking sdAbs have been successfully isolated from a llama immunized with human and mouse $\mathrm{TNF} \alpha$ which are more effective at neutralizing TNF $\alpha$ than the conventional TNF $\alpha$-blocking antibodies Infliximab and Adalimumab (Coppieters et al. 2006). Another Nb that binds to human IL-6-R and IL23 was generated for treatment of rheumatoid arthritis (Tillib et al. 2015; Desmyter et al. 2017).

Koch-Nolte et al. (2007) selected a novel Nb from an immunized phage display library directed against the $\mathrm{T}$ cell ecto-enzyme, ART2.2, which plays a key role in inflammatory settings and induces $\mathrm{T}$ cell death. Researchers demonstrate that these Nbs block effectively the enzymatic activity of ART2.2 in vivo.

Another study presented an interesting example of generating an ion-channel blocking $\mathrm{Nb}$. The $\mathrm{P} 2 \mathrm{X} 7$ ion channel is expressed by both monocytes and T cells. This ion channel responsible for the release of IL- $1 \beta$ during inflammation represents a potential therapeutic target in inflammatory diseases. It has been shown that sdAbs recognizing P2X7 were isolated from immunized llama effectively blocked ATPinduced the release of IL-1 $\beta$ with sub-nanomolar affinity (Danquah et al. 2016).

CXCL10 expression level increases in several diseases including SARS-CoV-2 infection. The group of SadeghianRizi et al. (2019) reported the isolation of anti-CXCL10 polyclonal HcAbs for the development of a specific Nbs that specifically target CXCL10 for in vivo therapeutic applications (Sadeghian-Rizi et al. 2019). Several VHHs targeting other chemokine receptors including CXCR4, CXCR7 and ChemR23 have been described (Jahnichen et al. 2010; Maussang et al. 2013; Peyrassol et al. 2016). Similarly, VHHs Blockade CCL2, CCL5, CXCL11 and CXCL12 have been selected by Blanchetot et al. (2013). The selected Nbs showed preventing chemokine receptor activation-induced immune cells migration in vitro.

The adaptive immune response in SARS-CoV had been extensively investigated. It was reported that CD4 + T cells promoted the proliferation of neutralizing antibodies, whereas $\mathrm{CD} 8+\mathrm{T}$ cells were responsible for the destruction of viral-infected cells. Increasing evidences have been reported that insufficient $T$ cell responses could play a decisive role in clearance of SARS-CoV (Rajaei and Dabbagh 2020; Vellingiri et al. 2020). In this context, targeted delivery of antigens to antigen presenting cells (APCs) improve immune responses by enhancing antibody production, activation of $\mathrm{CD}^{+} \mathrm{T}$ cells and elicitation of $\mathrm{CD}^{+} \mathrm{T}$ cell responses. MHC-II products, integrins (CD11b) and scavenger receptors (CD36) are abundantly expressed on APCs. Duarte et al. (2016) showed that VHHs specific for these molecules enhanced immune responses in distinct dendritic cells (DCs) populations. So, VHH can be used to deliver proteins or peptides to APCs to trigger humoral immunity and to track inflammation to treat or prevent SARS-CoV-2 infection.

\section{Conclusion}

The pandemic outbreak of COVID-19 is a potentially fatal and highly contagious disease. Apart from conventional antibodies produced by mammals, camelidae family members produce functional Heavy chain antibodies. These antibodies present a very small binding domain, named VHH or $\mathrm{Nb}$. The burst of VHH application in the last decades is highly apparent. Different VHH formats were developed for their use in therapeutic and/or diagnostic applications. Since there were peculiar characteristics like small size, low immunogenicity and high affinity and stability, combined with their easy expression as recombinant proteins, Nbs can be delivered to the infection site via inhalation. Neutralizing Nbs against the SARS-CoV-2 RBD have been successfully isolated. Some of them showed ultra-high affinity, excellent physicochemical properties after aerosolization, lyophilization and heat treatment which are desirable characteristics for a large-scale manufacturing. Selected Nbs represent an interesting approach to combat the COVID-19 re-emergence in the future. Thereby, VHHs may be of great benefit and could be an appropriate replacement for other therapeutics particularly for vulnerable population. In addition, they may find application in a cocktail of laboratory-synthesized neutralizing antibodies to enhance their neutralizing activities to reduce mutational escape, to treat severely ill COVID-19 patients and to mitigate future SARS-related $\mathrm{CoV}$ infections. Also, isolation of Nbs against chemokines, cytokines and ecto-enzymes indicates their potential utility as antiinflammatory and immune modulating agents to prevent and treat COVID-19 infection. So that, it can be given to frontline health care workers or immunocompromised patients to provide them long-term passive immune protection during COVID-19 pandemic.

Acknowledgements The authors are thankful to de la Rica R, Smolarek D and Esparza TJ for providing permission to reuse Figs. 1, 2 and 3 previously published.

Author contributions SB and SJ conceived the idea and wrote the manuscript. NM reviewed the manuscript before submission. IS contributed to the design in figures and table.TK and $\mathrm{MH}$ supervised and edited the manuscript. 


\section{Compliance with ethical standards}

Conflict of interest The authors declare that they have no conflict of interest in the publication.

\section{References}

Agostini ML, Andres EL, Sims AC, Graham RL, Sheahan TP, Lu X et al (2018) Coronavirus susceptibility to the antiviral remdesivir (GS-5734) is mediated by the viral polymerase and the proofreading exoribonuclease. MBio 9:1-15. https://doi.org/10.1128/ mBio.00221-218

Alkhowailed M, Shariq A, Alqossayir F, Alzahrani OA, Rasheed Z, Al Abdulmonem W (2020) Impact of meteorological parameters on COVID-19 pandemic: a comprehensive study from Saudi Arabia. Inform Med Unlocked 20:100418. https://doi.org/10.1016/j. imu.2020.100418

Ashour J, Schmidt FI, Hanke L, Cragnolini J, Cavallari M, Altenburg A et al (2015) Intracellular expression of camelid single-domain antibodies specific for influenza virus nucleoprotein uncovers distinct features of its nuclear localization. J Virol 89:2792-2800. https://doi.org/10.1128/JVI.02693-14

Blanc MR, Anouassi A, Ahmed Abed M, Tsikis G, Canepa S, Labas $\mathrm{V}$ et al (2009) A one-step exclusion-binding procedure for the purification of functional heavy-chain and mammalian-type gamma-globulins from camelid sera. Biotechnol Appl Biochem 54:207-212. https://doi.org/10.1042/BA20090208

Blanchetot C, Verzijl D, Mujić-Delić A, Bosch L, Rem L, Leurs R et al (2013) Neutralizing nanobodies targeting diverse chemokines effectively inhibit chemokine function. J Biol Chem 288:2517325182. https://doi.org/10.1074/jbc.M113.467969

Bontempi E (2020) The Europe second wave of COVID-19 infection and the Italy "strange" situation. Environ Res. https://doi. org/10.1016/j.envres.2020.110476

Cacciapaglia G, Cot C, Sannino F (2020) Second wave COVID-19 pandemics in Europe: a temporal playbook. Sci Rep 10:15514. https://doi.org/10.1038/s41598-020-72611-5

Cardoso FM, Ibañez LI, Van den Hoecke S, De Baets S, Smet A, Roose $\mathrm{K}$ et al (2014) Single-domain antibodies targeting neuraminidase protect against an $\mathrm{H} 5 \mathrm{~N} 1$ influenza virus challenge. J Virol 88:8278-8296. https://doi.org/10.1128/jvi.03178-13

Chames P, Rothbauer U (2020) Nanobody. Antibodies 9:6-9. https:// doi.org/10.3390/antib9010006

Chen Y, Liu Q, Guo D (2020b) Emerging coronaviruses: genome structure, replication, and pathogenesis. J Med Virol 92:418-423. https://doi.org/10.1002/jmv.25681

Chen X, Li R, Pan Z, Qian C, Yang Y, You R et al (2020a) Human monoclonal antibodies block the binding of SARS-CoV-2 spike protein to angiotensin converting enzyme 2 receptor. Cell Mol Immunol 17:647-649. https://doi.org/10.1038/s4142 3-020-0426-7

Chi X, Liu X, Wang C, Zhang X, Ren L, Jin Q et al (2020) Humanized single domain antibodies neutralize SARS-CoV-2 by targeting spike receptor binding domain. Nat Commun 11:1-7. https://doi. org/10.1101/2020.04.14.042010

Conrath K, Vincke C, Stijlemans B, Schymkowitz J, Decanniere K, Wyns L et al (2005) Antigen binding and solubility effects upon the veneering of a camel vhh in framework-2 to mimic a VH. J Mol Biol 350:112-125. https://doi.org/10.1016/j. jmb.2005.04.050
Coppieters K, Dreier T, Silence K, Haard HD, Lauwereys M, Casteels $P$ et al (2006) Formatted anti-tumor necrosis factor $\alpha$ VHH proteins derived from camelids show superior potency and targeting to inflamed joints in a murine model of collagen-induced arthritis. Arthritis Rheum 54:1856-1866. https://doi.org/10.1002/ art. 21827

Custodio TF, Das H, Sheward DJ, Hanke L, Pazicky S, Pieprzyk J et al (2020) Selection, biophysical and structural analysis of synthetic nanobodies that effectively neutralize SARS-CoV-2. Nat Commun 11:1-11. https://doi.org/10.1038/s41467-020-19204-y

Danquah W, Meyer-Schwesinger C, Rissiek B, Pinto C, SerracantPrat A, Amadi M et al (2016) Nanobodies that block gating of the P2X7 ion channel ameliorate inflammation. Sci Transl Med 8:366ra162-366ra162. https://doi.org/10.1126/scitranslm ed.aaf 8463

de la Rica R, Borges M, Gonzalez-Freire M (2020) COVID-19: in the eye of the cytokine storm. Front Immunol 11:2313. https://doi. org/10.3389/fimmu.2020.558898

De Marco A (2020) Recombinant expression of nanobodies and nanobody-derived immunoreagents. Protein Expres Purif 172:105645. https://doi.org/10.1016/j.pep.2020.105645

De Simone EA, Saccodossi N, Ferrari A, Leoni J (2008) Development of ELISAs for the measurement of $\operatorname{IgM}$ and $\operatorname{IgG}$ subclasses in sera from llamas (Lama glama) and assessment of the humoral immune response against different antigens. Vet Immunol Immunopathol 126:64-73. https://doi.org/10.1016/j. vetimm.2008.06.015

De Vlieger D, Ballegeer M, Rossey I, Schepens B, Saelens X (2019) Single-domain antibodies and their formatting to combat viral infections. Antibodies 8:1. https://doi.org/10.3390/antib8010001

Desmyter A, Spinelli S, Boutton C, Saunders M, Blachetot C, De Haard $\mathrm{H}$ et al (2017) Neutralization of human interleukin 23 by multivalent nanobodies explained by the structure of cytokine-nanobody complex. Front Immunol 8:884. https://doi.org/10.3389/fimmu .2017 .00884

Detalle L, Stohr T, Palomo C, Piedra PA, Gilbert BE, Mas V et al (2015) Generation and characterization of ALX-0171, a potent novel therapeutic nanobody for the treatment of respiratory syncytial virus infection. Antimicrob Agents Chemother 60:6-13. https://doi.org/10.1128/AAC.01802-15

Dong Y, Dai T, Wei Y, Zhang L, Zheng M, Zhou F (2020c) A systematic review of SARS-CoV-2 vaccine candidates. Sig Transduct Target Ther 5:237. https://doi.org/10.1038/s41392-020-00352-y

Dong J, Huang B, Wang B, Titong A, Kankanamalage SG, Jia Z et al (2020b) Development of humanized tri-specific nanobodies with potent neutralization for SARS-CoV-2. Sci Rep 10:1-12. https:// doi.org/10.1038/s41598-020-74761-y

Dong J, Huang B, Jia Z, Wang B, Kankanamalage SG, Titong A, Liu Y (2020a) Development of multi-specific humanized llama antibodies blocking SARS-CoV-2/ACE2 interaction with high affinity and avidity. Emerg Microbes Infect 9:1034-1036. https://doi. org/10.1080/22221751.2020.1768806

Duarte JN, Cragnolini JJ, Swee LK, Bilate AM, Bader J, Ingram JR et al (2016) Generation of Immunity against Pathogens via Single-Domain Antibody-Antigen Constructs. J Immunol 197:48384847. https://doi.org/10.4049/jimmunol.1600692

Dumoulin M, Conrath K, Van Meirhaeghe A, Meersman F, Heremans K, Frenken LG et al (2002) Single-domain antibody fragments with high conformational stability. Protein Sci 11:500-515. https ://doi.org/10.1110/ps.34602

Esparza TJ, Brody D L (2020) High Affinity Nanobodies Block SARSCoV-2 Spike Receptor Binding Domain Interaction with Human Angiotensin Converting Enzyme. bioRxiv 2007.2024.219857, 694. https://doi:https://doi.org/10.1101/2020.07.24.219857

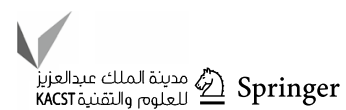


Forsman A, Beirnaert E, Aasa-Chapman M M, Hoorelbeke B, Hijazi $\mathrm{K}$, Koh W et al (2008) Llama antibody fragments with cross-subtype human immunodeficiency virus type 1 (HIV-1)-neutralizing properties and high affinity for HIV-1 gp120. J Virol 82: 1206912081. https:// doi.org/https://doi.org/10.1128/JVI.01379-08

Gai J, Ma L, Li G, Zhu M, Qiao P, Li X et al (2020) A potent neutralizing nanobody against SARS-CoV-2 with inhaled delivery potential. BioRxiv. https://doi.org/10.1101/2020.08.09.242867

Gao J, Tian Z, Yang X (2020) Breakthrough: Chloroquine phosphate has shown apparent efficacy in treatment of COVID-19 associated pneumonia in clinical studies. BioSci Trends 14:72-73. https://doi.org/10.5582/bst.2020.01047

Gautret P, Lagier J, Parola P, Hoang VT, Meddeb L, Mailhe M et al (2020) Hydroxychloroquine and azithromycin as a treatment of COVID-19: Results of an open-label non-randomized clinical trial. Int J Antimicrob Ag 56:105949. https://doi.org/10.1016/j. ijantimicag.2020.105949

Gharbharan A, Jordans CC, GeurtsvanKessel C, den Hollander JG, Karim F, Mollema FP et al (2020) Convalescent Plasma for COVID-19. MED Rxiv, A randomized clinical trial. https://doi. org/10.1101/2020.07.01.2013985

Glass DH (2020) European and US lockdowns and second waves during the COVID-19 pandemic. Math Biosci 330:108472. https:// doi.org/10.1016/j.mbs.2020.108472

Guo C, Bo Y, Lin C, Li HB, Zeng Y, Zhang Y et al (2020) Meteorological factors and COVID-19 incidence in 190 countries: an observational study. Sci Total Environ. https://doi.org/10.1016/j. scitotenv.2020.143783

Hamers-Casterman C, Atarhouch T, Muyldermans S, Robinson G, Hamers C, Songa EB et al (1993) Naturally occurring antibodies devoid of light chains. Nature 363:446-448. https://doi. org $/ 10.1038 / 363446 \mathrm{a} 0$

Hanke L, Perez LV, Sheward DJ, Das H, Schulte T, Morro AM et al (2020) An alpaca nanobody neutralizes SARS-CoV-2 by blocking receptor interaction. bioRxiv. https://doi. org/10.1101/2020.06.02.130161

He L, Tai W, Li J, Chen Y, Gao Y, Li J et al (2019) Enhanced ability of oligomeric nanobodies targeting MERS coronavirus receptor-binding domain. Viruses 11:166. https://doi.org/10.3390/ v11020166

Hufton SE, Risley P, Ball CR, Major D, Engelhardt OG, Poole S (2014) The breadth of cross sub-type neutralisation activity of a single domain antibody to influenza hemaglutinin can be increased by antibody valency. PLoS ONE 9:e103294. https:// doi.org/10.1371/journal.pone.0103294

Hultberg A, Temperton NJ, Rosseels V, Koenders M, GonzalezPajuelo M, Schepens B et al (2011) Llama-derived single domain antibodies to build multivalent, superpotent and broadened neutralizing anti-viral molecules. PLoS ONE 6:1-12. https://doi.org/10.1371/journal.pone.0017665

Huo J, Le Bas A, Ruza RR, Duyvesteyn HM, Mikolajek H, Malinauskas T et al (2020) Structural characterisation of a nanobody derived from a naïve library that neutralises SARS-CoV-2. Nat Struct Mol Biol 27:846-854. https://doi.org/10.21203/ rs.3.rs-32948/v1

Jackson LA, Anderson EJ, Rouphael NG, Roberts PC, Makhene $\mathrm{M}$, Coler RN et al (2020) An mRNA vaccine against SARSCoV-2-preliminary report. N Engl J Med 383:1920-1931. https://doi.org/10.1056/NEJMoa2022483

Jähnichen S, Blanchetot C, Maussang D, Gonzalez-Pajuelo M, Chow KY, Bosch L et al (2010) CXCR4 nanobodies (VHH-based single variable domains) potently inhibit chemotaxis and HIV-1 replication and mobilize stem cells. Proc Natl Acad Sci 107:20565-20570. https://doi.org/10.1073/pnas.1012865107
Jovčevska I, Muyldermans S (2020) The therapeutic potential of nanobodies. Bio Drugs 34:11-26. https://doi.org/10.1007/ s40259-019-00392-z

Ju B, hang Q, Ge X, Wang R, Yu J, Shan S, et al (2020) Potent human neutralizing antibodies elicited by SARS-CoV-2 infection (2020). bioRxiv. https://doi.org/10.1101/2020.03.21.990770

Khodabakhsh F, Behdani M, Rami A, Kazemi-Lomedasht F (2018) Single-domain antibodies or nanobodies: a class of next-generation antibodies. Int Rev Immunol 37:316-322. https://doi. org/10.1080/08830185.2018.1526932

Kissler SM, Tedijanto C, Goldstein E, Grad YH, Lipsitch M (2020) Projecting the transmission dynamics of SARS-CoV-2 through the postpandemic period. Science 368:860-868. https://doi. org/10.1126/science.abb5793

Klasse P J, Moore J P (2020) Antibodies to SARS-CoV-2 and Their Potential for Therapeutic Passive Immunization. Preprints 2020040326. doi: https://doi.org/10.20944/preprints202004 .0326.v1

Ko JH, Seok H, Cho SY, Ha YE, Baek JY, Kim SH et al (2018) Challenges of convalescent plasma infusion therapy in Middle East respiratory coronavirus infection: a single centre experience. Antivir Ther 23:617-622. https://doi.org/10.3851/imp3243

Koch-Nolte F, Reyelt J, Schößow B, Schwarz N, Scheuplein F, Rothenburg S et al (2007) Single domain antibodies from llama effectively and specifically block T cell ecto-ADP-ribosyltransferase ART2. 2 in vivo. FASEB J 21:3490-3498. https://doi. org/10.1096/fj.07-8661 com

Koromyslova AD, Hansman GS (2017) Nanobodies targeting norovirus capsid reveal functional epitopes and potential mechanisms of neutralization. PLoS Pathog 13:e1006636. https://doi. org/10.1371/journal.ppat.1006636

Kunz P, Zinner K, Mücke N, Bartoschik T, Muyldermans S, Hoheisel JD (2018) The structural basis of nanobody unfolding reversibility and thermoresistance. Sci Rep 8:7934. https://doi. org/10.1038/s41598-018-26338-z

Lafaye P, Li T (2018) Use of camel single-domain antibodies for the diagnosis and treatment of zoonotic diseases. Comp Immunol Microb 60:17-22. https://doi.org/10.1016/j.cimid.2018.09.009

Laursen NS, Friesen RH, Zhu X, Jongeneelen M, Blokland S, Vermond $J$ et al (2018) Universal protection against influenza infection by a multidomain antibody to influenza hemaglutinin. Science 362:598-602. https://doi.org/10.1126/science.aaq0620

Li T, Li T, Cai H, Yao H, Zhou B, Zhao Y et al (2020a) Potent synthetic nanobodies against SARS-CoV-2 and molecular basis for neutralization. bioRxiv 1-18. https://doi.org/10.1101/2020.06.09.14343 8

Li X, Geng M, Peng Y, Meng L, Lu S (2020b) Molecular immune pathogenesis and diagnosis of COVID-19. J Pharm Anal 10:102108. https://doi.org/10.1016/j.jpha.2020.03.001

Liu Y, Huang H (2018) Expression of single-domain antibody in different systems. Appl Microbiol Biotechnol 102:539-551. https ://doi.org/10.1007/s00253-017-8644-3

Liu JL, Shriver-Lake LC, Anderson GP, Zabetakis D, Goldman ER (2017) Selection, characterization, and thermal stabilization of llama single domain antibodies towards Ebola virus glycoprotein. Microb Cell Fact 16:223. https://doi.org/10.1186/s1293 4-017-0837-z

Liu JL, Shriver-Lake LC, Zabetakis D, Anderson GP, Goldman ER (2019) Selection and characterization of protective anti-chikungunya virus single domain antibodies. Mol Immunol 105:190197. https://doi.org/10.1016/j.molimm.2018.11.016

Logunov DY, Dolzhikova IV, Zubkova OV, Tukhvatullin AI, Shcheblyakov DV, Dzharullaeva AS et al (2020) Safety and immunogenicity of an rAd26 and rAd5 vector-based heterologous prime-boost COVID-19 vaccine in two formulations: two open, 
non-randomised phase 1/2 studies from Russia. Lancet 396:887897. https://doi.org/10.1016/S0140-6736(20)31866-3

Lu H (2020) Drug treatment options for the 2019-new coronavirus (2019-nCoV). Biosci Trends 14:69-71. https://doi.org/10.5582/ bst.2020.01020

Lu R, Zhao X, Li J, Niu P, Yang B, Wu H et al (2020) Genomic characterisation and epidemiology of 2019 novel coronavirus: implications for virus origins and receptor binding. Lancet 395:565-574. https://doi.org/10.1016/S0140-6736(20)30251-8

Maussang D, Mujić-Delić A, Descamps FJ, Stortelers C, Vanlandschoot P, Stigter-van Walsum M et al (2013) Llama-derived single variable domains (nanobodies) directed against chemokine receptor CXCR7 reduce head and neck cancer cell growth in vivo. J Biol Chem 288:29562-29572. https://doi.org/10.1074/ jbc.M113.498436

Mishra D, Mishra A, Chaturvedi VK, Singh MP (2020) An overview of COVID-19 with an emphasis on computational approach for its preventive intervention. Biotechnology 10:1-13. https://doi. org/10.1007/s13205-020-02425-9

Miyara M, Sterlin D, Anna F, Marot S, Mathian A, Atif M et al (2020) Pre-COVID-19 humoral immunity to common coronaviruses does not confer cross-protection against SARS-CoV-2. medRxiv. https://doi.org/10.1101/2020.08.14.20173393

Morrison C (2019) Nanobody approval gives domain antibodies a boost. Nature Rev Drug Discov 18:485-487. https://doi. org/10.1038/d41573-019-00104-w

Muyldermans S, Atarhouch T, Saldanha J, Barbosa JARG, Hamers R (1994) Sequence and structure of VH domain from naturally occurring camel heavy chain immunoglobulins lacking light chains. Protein Eng Des Sel 7:1129-1135. https://doi. org/10.1093/protein/7.9.1129

Nguyen VK, Desmyter A, Muyldermans S (2001) Functional heavychain antibodies in Camelidae. Adv Immunol 79:261-296. https ://doi.org/10.1016/S0065-2776(01)79006-2

Nieto GEV, Jara R, Himelreichs J, Salinas C, Pinto T, Cheuquemilla $Y$ et al (2020) Fast isolation of sub-nanomolar affinity alpaca nanobody against the Spike RBD of SARS-CoV-2 by combining bacterial display and a simple single-step density gradient selection. bioRxiv. https://doi.org/10.1101/2020.06.09.137935

Nosenko MA, Atretkhany KSN, Mokhonov VV, Efimov GA, Kruglov AA, Tillib SV et al (2017) VHH-based bispecific antibodies targeting cytokine production. Front Imunol 8:1073. https://doi. org/10.3389/fimmu.2017.01073

Ong EZ, Chan YFZ, Leong WY, Lee NMY, Kalimuddin S, Mohideen SMH et al (2020) A dynamic immune response shapes COVID19 progression. Cell Host Microbe. https://doi.org/10.1016/j. chom.2020.03.021

Pedro SA, Ndjomatchoua FT, Jentsch P, Tcheunche JM, Anand M, Bauch CT (2020) Conditions for a second wave of COVID19 due to interactions between disease dynamics and social processes. Front Phys 8:574514. https://doi.org/10.3389/ fphy.2020.574514

Petersen E, Koopmans M, Go U, Hamer DH, Petrosillo N, Castelli F et al (2020) Comparing SARS-CoV-2 with SARS-CoV and influenza pandemics. Lancet Infect Dis 20:238-244. https://doi. org/10.1016/S1473-3099(20)30484-9

Peyrassol X, Laeremans T, Gouwy M, Lahura V, Debulpaep M, Van Damme J et al (2016) Development by genetic immunization of monovalent antibodies (nanobodies) behaving as antagonists of the human ChemR23 receptor. J Immunol 196:2893-2901. https ://doi.org/10.4049/jimmunol.1500888

Prévost J, Gasser R, Beaudoin-Bussières G, Richard J, Duerr R, Laumaea A et al (2020) Cross-sectional evaluation of humoral responses against SARS-CoV-2 Spike. Cell Rep Med 1:100126. https://doi.org/10.1016/j.xcrm.2020.100126
Qi H, Xiao S, Shi R, Ward MP, Chen Y, Tu W et al (2020) Covid19 transmission in Mainland China is associated with temperature and humidity: a time-series analysis. Sci Total Environ 728:138778. https://doi.org/10.1016/j.scitotenv.2020.138778

Raj VS, Okba NM, Gutierrez-Alvarez J, Drabek D, Van Dieren B, Widagdo W et al (2018) Chimeric camel/human heavy-chain antibodies protect against MERS-CoV infection. Sci Adv 4:9667. https://doi.org/10.1126/sciadv.aas9667

Rajaei S, Dabbagh A (2020) The immunologic basis of COVID-19: a clinical approach. J Cell Mol Anesth 5:37-42. https://doi. org/10.22037/jcma.v5i1.29778

Renardy M, Eisenberg M, Kirschner D (2020) Predicting the second wave of COVID-19 in Washtenaw County. MI J Theor Biol 507:110461. https://doi.org/10.1016/j.jtbi.2020.110461

Renn A, Fu Y, Hu X, Hall MD, Simeonov A (2020) Fruitful neutralizing antibody pipeline brings hope to defeat SARS-Cov-2. Trends Pharmacol Sci 41:815-829. https://doi.org/10.1016/j. tips.2020.07.004

Sadeghian-Rizi T, Behdani M, Khanahmad H, Ghasemi-Dehkordi P, Sadeghi HM, Jahanian-Najafabadi A (2019) Production of novel camelid anti-CXCL10 specific polyclonal antibodies and evaluation of their bioreactivity. Int J Pept Res Ther 25:535-540. https ://doi.org/10.1007/s10989-018-9697-6

Sajadi MM, Habibzadeh P, Vintzileos A, Shokouhi S, Miralles-Wilhelm F, Amoroso A (2020) Temperature, humidity, and latitude analysis to estimate potential spread and seasonality of coronavirus disease 2019 (COVID-19). JAMA Netw Open 3:e2011834. https://doi.org/10.1001/jamanetworkopen.2020.11834

Sanaei M, Setayesh N, Sepehrizadeh Z, Mahdavi M, Yazdi MH (2019) Nanobodies in human infections: prevention, detection, and treatment. Immunol Invest. https://doi.org/10.1080/08820 139.2019.1688828

Schoof M, Faust B, Saunders AR, Sangwan S, Rezelj V, Hoppe N et al (2020) An ultrahigh affinity synthetic nanobody blocks SARS-CoV-2 infection by locking Spike into an inactive conformation. bioRxiv. https://doi.org/10.1101/2020.08.08.238469

Seow J, Graham C, Merrick B, Acors S, Pickering S, Steel KJ et al (2020) Longitudinal observation and decline of neutralizing antibody responses in the three months following SARS-CoV-2 infection in humans. Nat Microbiol 5:1598-1607. https://doi. org/10.1038/s41564-020-00813-8

Serruys B, Van Houtte F, Farhoudi-Moghadam A, Leroux-Roels G, Vanlandschoot P (2010) Production, characterization and in vitro testing of $\mathrm{HBcAg}$-specific VHH intrabodies. J Gen Virol 91:643-652. https://doi.org/10.1099/vir.0.016063-0

Sheahan TP, Sims AC, Graham RL, Menachery VD, Gralinski LE, Case JB et al (2017) Broad-spectrum antiviral GS-5734 inhibits both epidemic and zoonotic coronaviruses. Sci Transl Med 9:1-11. https://doi.org/10.1126/scitranslmed.aal3653

Shi Y, Wang Y, Shao C, Huang J, Gan J, Huang X et al (2020) COVID-19 infection: the perspectives on immune responses. Cell Death Differ. https://doi.org/10.1038/s41418-020-0530-3

Silacci M, Brack S, Schirru G, Mårlind J, Ettorre A, Merlo A et al (2005) Design, construction, and characterization of a large synthetic human antibody phage display library. Proteomics 5:2340-2350. https://doi.org/10.1002/pmic.200401273

Smolarek D, Bertrand O, Czerwinski M (2012) Variable fragments of heavy chain antibodies (VHHs): a new magic bullet molecule of medicine? Postepy Hig Med Dosw 66:348-358

Sroga P, Safronetz D, Stein DR (2020) Nanobodies: a new approach for the diagnosis and treatment of viral infectious diseases. Future Virol 15:195-205. https://doi.org/10.2217/ fvl-2019-0167

Stanfield RL, Dooley H, Flajnik MF, Wilson IA (2004) Crystal structure of a shark single-domain antibody $\mathrm{V}$ region in complex with

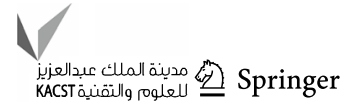


lysozyme. Science 305:1770-1773. https://doi.org/10.1126/scien ce. 1101148

Strauss M, Schotte L, Thys B, Filman DJ, Hogle JM (2016) Five of five VHHs neutralizing poliovirus bind the receptor-binding site. $\mathrm{J}$ Virol 90:3496-3505. https://doi.org/10.1128/JVI.03017-15

Strokappe N, Szynol A, Aasa-Chapman M, Gorlani A, Quigley AF, Hulsik DL et al (2012) Llama antibody fragments recognizing various epitopes of the CD4bs neutralize a broad range of HIV-1 subtypes A B and C. PLoS ONE 7:e33298. https://doi. org/10.1371/journal.pone.0033298

Terryn S, Francart A, Rommelaere H, Stortelers C, Van Gucht S (2016) Post-exposure treatment with anti-rabies VHH and vaccine significantly improves protection of mice from lethal rabies infection. PLOS Negl Trop Dis 10:1-15. https://doi.org/10.1371/journ al.pntd.0004902

Tillib SV, Efimov GA, Gubernatorova EO, Goryainova OS, Ivanova TI, Bocharov AA et al (2015) Preparation and characterization of recombinant single-chain llama antibodies that specifically bind to human interleukin-6. Russ J Immunol 9:400-409

Tse V, Meganck RM, Graham RL, Baric RS (2020) The current and future state of vaccines, antivirals and gene therapies against emerging coronaviruses. Front Microbiol 11:658. https://doi. org/10.3389/fmicb.2020.00658

Van der Linden RH, Frenken LG, De Geus B, Harmsen MM, Ruuls RC, Stok W et al (1999) Comparison of physical chemical properties of llama VHH antibody fragments and mouse monoclonal antibodies. Biochim Biophys Acta 14:37-46. https://doi.org/10.1016/ S0167-4838(99)00030-8

Van der Vaart JM, Pant N, Wolvers D, Bezemer S, Hermans PW, Bellamy K et al (2006) Reduction in morbidity of rotavirus induced diarrhoea in mice by yeast produced monovalent llamaderived antibody fragments. Vaccine 24:4130-4137. https://doi. org/10.1016/j.vaccine.2006.02.045

Van Heeke G, Allosery K, De Brabandere V, De Smedt T, Detalle L, de Fougerolles A (2017) Nanobodies ${ }^{\circledR}$ as inhaled biotherapeutics for lung diseases. Pharmacol Ther 169:47-56. https://doi. org/10.1016/j.pharmthera.2016.06.012

Vashishtha VM, Kumar P (2020) Development of SARS-CoV-2 vaccines: challenges, risks, and the way forward. Hum Vaccines Immunother. https://doi.org/10.1080/21645515.2020.1845524

Vellingiri B, Jayaramayya K, Iyer M, Narayanasamy A, Govindasamy V, Giridharan B et al (2020) COVID-19: A promising cure for the global panic. Sci Total Environ. https://doi.org/10.1016/j.scito tenv.2020.138277

Vu KB, Ghahroudi MA, Wyns L, Muyldermans S (1997) Comparison of llama $\mathrm{VH}$ sequences from conventional and heavy chain antibodies. Mol Immunol 34:1121-1131. https://doi.org/10.1016/ S0161-5890(97)00146-6

Wagner TR, Kaiser PD, Gramlich M, Becker M, Traenkle B, Junker D et al (2020) NeutrobodyPlex-Nanobodies to monitor a SARSCoV-2 neutralizing immune response. bioRxiv. https://doi. org/10.1101/2020.09.22.308338

Walter JD, Hutter CA, Zimmermann I, Earp J, Egloff P, Sorgenfrei $M$ et al (2020) Synthetic nanobodies targeting the SARS-CoV-2 receptor-binding domain. BioRxiv. https://doi. org/10.1101/2020.04.16.045419

Wang SM, He X, Li N, Yu F, Hu Y, Wang LS et al (2015) A novel nanobody specific for respiratory surfactant protein A has potential for lung targeting. Int J Nanomed 10:2857-2869. https://doi. org/10.2147/IJN.S77268

Wang C, Li W, Drabek D, Okba NM, van Haperen R, Osterhaus AD et al (2020a) Human monoclonal antibody blocking SARS-CoV-2 infection. Nat Commun 11:1-6. https://doi.org/10.1038/s4146 7-020-16256-ypmid:32366817

Wang LS, Wang YR, Ye DW, Liu QQ (2020b) A review of the 2019 Novel Coronavirus (COVID-19) based on current evidence. Int J Antimicrob Agents. https://doi.org/10.1016/j.ijantimica g.2020.105948

Wang X, Cao R, Zhang H, Liu J, Xu M, Hu H et al (2020c) The antiinfluenza virus drug, arbidol is an efficient inhibitor of SARSCoV-2 in vitro. Cell Discov 6:1-5. https://doi.org/10.1038/s4142 1-020-0169-8

Wei G, Meng W, Guo H, Pan W, Liu J, Peng T et al (2011) Potent neutralization of influenza A virus by a single-domain antibody blocking M2 ion channel protein. PLoS ONE. https://doi. org/10.1371/journal.pone.0028309

Weiss RA, Verrips CT (2019) Nanobodies that neutralize HIV. Vaccines 7:77. https://doi.org/10.3390/vaccines7030077

Wen W, Su W, Tang H, Le W, Zhang X, Zheng Y et al (2020) Immune cell profiling of COVID-19 patients in the recovery stage by single-cell sequencing. Cell Discov 6:1-18. https://doi.org/10.1038/ s41421-020-0168-9

Wesolowski J, Alzogaray V, Reyelt J, Unger M, Juarez K, Urrutia $M$ et al (2009) Single domain antibodies: promising experimental and therapeutic tools in infection and immunity. Med Microbiol Immune 198:157-174. https://doi.org/10.1007/s0043 0-009-0116-7

Wilken L, McPherson A (2018) Application of camelid heavy-chain variable domains (VHHs) in prevention and treatment of bacterial and viral infections. Int Rev Immunol 37:69-76. https://doi. org/10.1080/08830185.2017.1397657

Wrapp D, De Vlieger D, Corbett KS, Torres GM, Wang N, Van Breedam W et al (2020a) Structural basis for potent neutralization of betacoronaviruses by single-domain camelid antibodies. Cell 181:1004-1015. https://doi.org/10.1016/j.cell.2020.04.031

Wrapp D, Wang N, Corbett KS, Goldsmith JA, Hsieh CL, Abiona O et al (2020b) Cryo-EM structure of the 2019-nCoV spike in the prefusion conformation. Science 367:1260-1263. https://doi. org/10.1126/science.abb2507

Wu Y, Li C, Xia S, Tian X, Wang Z, Kong Y et al (2020) Fully human single-domain antibodies against SARS-CoV-2. bioRxiv. https ://doi.org/10.1101/2020.03.30.015990

Xiang Y, Nambulli S, Xiao Z, Li H, Sang Z, Duprex WP et al (2020) Versatile and multivalent nanobodies efficiently neutralize SARS-CoV-2. Science 370:1479-1484. https://doi.org/10.1126/ science.abe 4747

Yao H, Cai H, Li T, Zhou B, Qin W, Lavillette D et al (2020) A high-affinity RBD-targeting nanobody improves fusion partner's potency against SARS-CoV-2. bioRxiv. https://doi. org/10.1101/2020.09.24.312595

Zhao G, He L, Sun S, Qiu H, Tai W, Chen J et al (2018) A novel nanobody targeting Middle East respiratory syndrome coronavirus (MERS-CoV) receptor-binding domain has potent crossneutralizing activity and protective efficacy against MERS-CoV. J Virol 92:e00837-e918. https://doi.org/10.1128/JVI.00837-18

Zhou D, Duyvesteyn HME, Chen CP, Huang CG, Chen TH, Shih SR et al (2020a) Structural basis for the neutralization of SARS-CoV-2 by an antibody from a convalescent patient. Nat Struct Mol Biol 27:950-958. https://doi.org/10.1038/s4159 4-020-0480-y

Zhou P, Yang XL, Wang XG, Hu B, Zhang L, Zhang W et al (2020b) A pneumonia outbreak associated with a new coronavirus of probable bat origin. Nature 579:270-273. https://doi.org/10.1038/ s41586-020-2012-7 